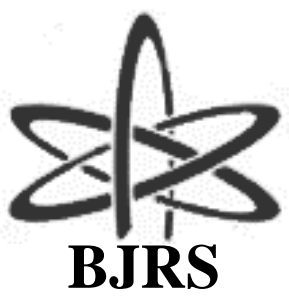

\author{
BRAZILIAN JOURNAL \\ $\mathrm{OF}$ \\ RADIATION SCIENCES \\ 09-01A (2021) 01-16
}

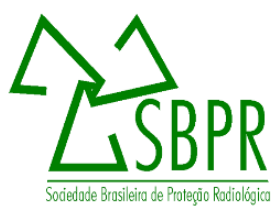

\title{
Analysis of the pigments in two modern Egyptian papyri using XRF technique
}

\author{
Nardes $^{\mathrm{a}}$ R.C., Sanches ${ }^{\mathrm{a}}$ F.A.C.R.A., Gama Filho ${ }^{\mathrm{a}}$ H., Santos ${ }^{\mathrm{a}}$ R.S., Brancaglion Jr ${ }^{\mathrm{b}}$, \\ A., Chapot ${ }^{\mathrm{b}}$, G., Freitas ${ }^{\mathrm{c}}$, R.P., Assis ${ }^{\mathrm{d}}$, J.T., Anjos ${ }^{\mathrm{a}}$, M.J. \\ ${ }^{a}$ Universidade do Estado do Rio de Janeiro, Instituto de Física, 20550-900, Rio de Janeiro, RJ, Brasil \\ rc.nardes@gmail.com; francissanches@gmail.com; ramonziosp@yahoo.com.br; marcelin@uerj.br \\ ${ }^{b}$ Museu Nacional, Universidade Federal do Rio de Janeiro, 20940-040 Rio de Janeiro, RJ, Brasil \\ inpw@yahoo.com; gisachapot@gmail.com \\ ${ }^{c}$ Laboratório de Instrumentação e Simulação Computacional, Instituto Federal de Educação, Ciência e Tecnologia do \\ Rio de Janeiro, 26600-000 Paracambi, RJ, Brasil. \\ renato.freitas@ifrj.edu.br \\ ${ }^{d}$ Universidade do Estado do Rio de Janeiro, Instituto Politécnico, 28625-570 Nova Friburgo, RJ, Brasil
} joaquim.iprj@gmail.com

\begin{abstract}
In this work, two modern Egyptian papyrus belonging to a private collection were analyzed using X-Ray Fluorescence technique (XRF). The papyri are genuine, made from the papyrus plant, and hand-painted. The papyri were bought in the city of Cairo, Egypt, in the '80s and brought to Brazil in the same period. XRF analyses were performed using a portable spectrometer ARTTAX (X-ray tube with Mo anode and a Silicon Drift Detector XFlash ${ }^{\circledR}$, Bruker AXS Inc.). XRF measurements were carried out under the following experimental conditions: $35 \mathrm{kV}, 600 \mu \mathrm{A}$, unfiltered $\mathrm{x}$-ray beam, air atmosphere, acquisition time of $600 \mathrm{~s}$. The elements detected in the two papyri were: $\mathrm{Si}, \mathrm{Al}, \mathrm{S}, \mathrm{Cl}, \mathrm{K}, \mathrm{Ca}, \mathrm{Ti}, \mathrm{Cr}, \mathrm{Mn}, \mathrm{Fe}, \mathrm{Ni}, \mathrm{Cu}, \mathrm{Zn}, \mathrm{Sr}$, Ba and Pb. Through the XRF analysis it was possible to evaluate the pigments found in the two papyri are different from each other. In the analysis of the blue color, present in the papyrus, it was observed that the composition of this color can be a mixture of two pigments: Egyptian blue $\left(\mathrm{CaCuSi}_{4} \mathrm{O}_{10}\right)$ and Lithopone $\left(\mathrm{ZnSBaSO}_{4}\right)$. Most of the pigments on the papyri were thus recognized to be modern, their syntheses, or refinement processes not being known to ancient Egyptians.
\end{abstract}

Keywords: XRF Technique, Modern papyrus, Pigments. 


\section{INTRODUCTION}

Papyrus was the most popular writing material in the world. Before it was replaced by paper, papyrus was a writing material as early as 3,000 BC in ancient Egypt and continued to be used to some extent until around $1100 \mathrm{AD}$ [1]. Nowadays, modern papyrus is used by artists and calligraphers [2]. Papyrus paintings depicting the daily life, mythology, gods, and goddesses of ancient Egypt attract admirers from all corners of the globe of this long and rich history of Egypt, making papyrus art a good reminder of this fascinating place. A relevant subject of study in the sphere of ancient Egyptians is pigment characterization. Many studies can be found in the vast corpus of pigments used in ancient Egyptian [3, 4].

$\mathrm{X}$-ray fluorescence $(\mathrm{XRF})$ is one of the most widely used nondestructive techniques in the analysis of artwork and cultural heritage, providing the elemental composition of the studied artifact. The analytical identification of pigment through the XRF technique involves its color and elemental composition, i.e., the presence of specific key elements $[5,6]$.

Since the chronology of pigments use is well established in the literature, it is possible to determine in some cases - based on the analysis of XRF spectra - the provenance, historical period, and, consequently, the authenticity of a painting or artifact. Besides that, the information obtained from the XRF analysis can help in the identification of forgeries and the evaluation of conservation and restoration procedures, allowing the cultural heritage of ancient civilizations to live forever [8, 9].

In this work, two modern Egyptian papyrus belonging to a private collection were analyzed using XRF technique. These papyri are genuine, made from the papyrus plant and hand-painted. Both papyri were bought in the city of Cairo, Egypt, in the ' 80 s and brought to Brazil in the same period. The purpose of this work was to identify the elemental composition of the pigments that are employed in modern Egyptian hand-painted papyrus artwork and to compare them with the pigments used in the art of ancient Egypt.

\section{MATERIALS AND METHODS}




\subsection{Samples}

Two modern papyri belonging to a private collection in Rio de Janeiro were examined using the X-Ray Fluorescence technique (XRF). The papyri in this study were named papyrus 1 and papyrus 2. Papyri were bought to Cairo in the ' 80 s and brought to Brazil in the same period. Both papyri are genuine, made from the papyrus plant and hand-painted.

\subsubsection{Papyrus 1}

Papyrus 1 is a famous scene of king Tutankhamun and his wife Ankhesenamun (Fig. 1). Tutankhamun (18th dynasty, 14th C. BC) became pharaoh was about nine years old after the death of his father Akhenaten. At about the age of eighteen or nineteen, Tutankhamun died suddenly, leaving Ankhesenamun alone. The discovery of his tomb was in 1922 [10]. The painting is a scene of the Tutankhamun receiving an offering from his wife. Papyrus's size $32.8 \mathrm{~cm}$ x $41.2 \mathrm{~cm}$.

Figure 1: Papyrus 1-King Tutankhamun and his wife.

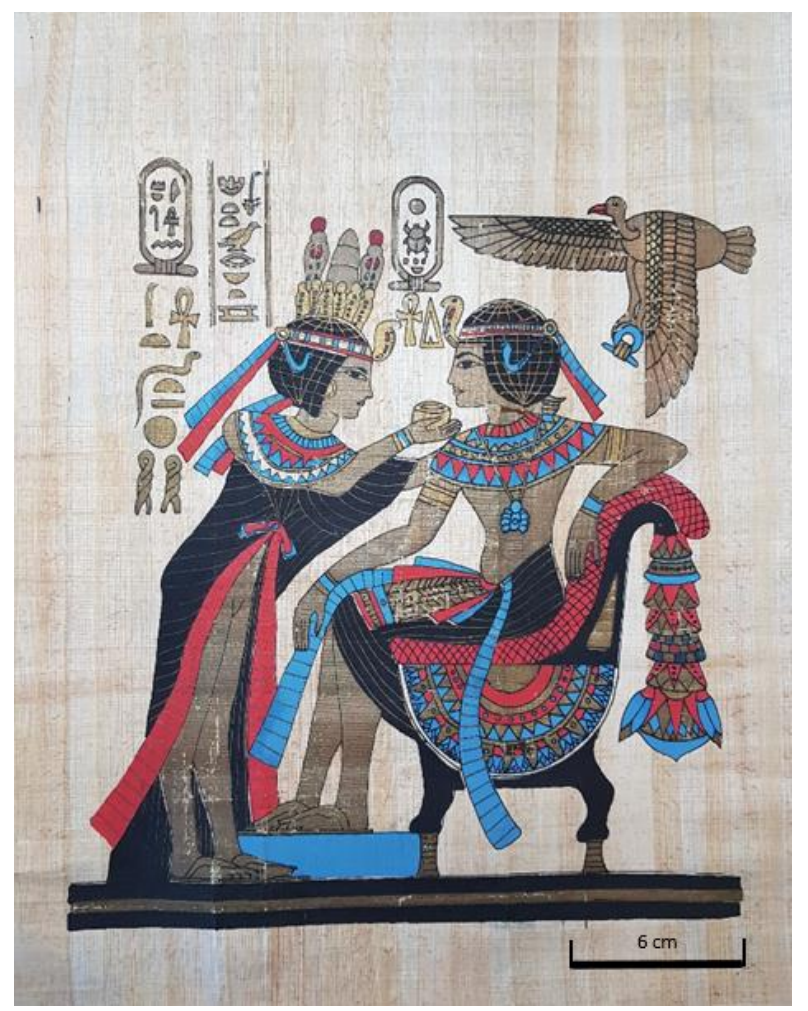




\subsubsection{Papyrus 2}

The other papyrus analyzed (papyrus 2) is a hunting scene of the Tomb of Nakht (Figure 2). Holding the title the "scribe" and the other title "serving priest of Amon" at the Karnak temple, probably during the 18th dynasty. The Tomb of Nakht was discovered by European explorers in 1889. This painting is a double scene, with flocks of rising birds. Nakht is portrayed with his wife and two small sons in a papyrus boat, grasping a hunting stick [11]. Papyrus's size $31,5 \mathrm{~cm} \times 44,8$ $\mathrm{cm}$.

Figure 2: Papyrus 2 - The hunting scene of the Tomb of Nakht.

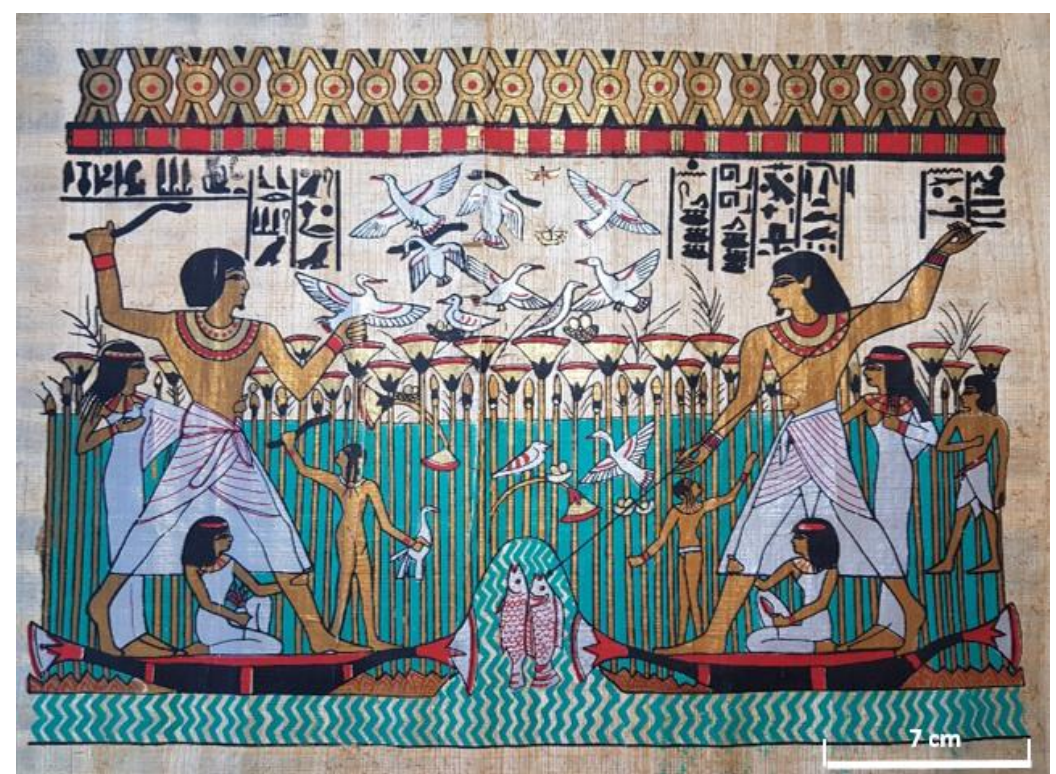

\subsection{XRF analysis}

The two papyri were analyzed using the ARTAX 200 equipment. ARTAX 200 system (Bruker), consisting in an air-cooled that it has a Mo anode X-ray tube and an X Flash SDD detector (Silicon Drift Detector) with an energy resolution of $145 \mathrm{eV}$ for the $\mathrm{Mn}-\mathrm{K}_{\alpha}$ energy line. The XRF analyses were performed at three different points in each region, totaling 33 points. The analyses were performed with a voltage and current of $35 \mathrm{kV}$ and $600 \mu \mathrm{A}$, respectively, and a measurement time of $600 \mathrm{~s}$. The X-ray beam size on the sample is $600 \mu \mathrm{m}$ (beam diameter). An integrated CCD 
camera providing a magnified digital image of the sample region under investigation. In addition, there is a white LED that illuminates the sample to optimize image quality and contrast. On the other hand, a red laser diode is used to control the exact position of the X-ray beam on the sample. So, the laser spot is adjusted to the focus of the mini lens and recorded by the CCD camera, in this way, the operator can always see the exact position of the X-ray beam in the video window of the system software running on a connected notebook.

All the XRF-Spectra were evaluated using the open source PyMCA software package [12]. Figure 3 shows papyrus 1 being positioned for XRF measurements.

Figure 3: ARTAX with zoom of geometric set-up of the X-ray beam on the sample

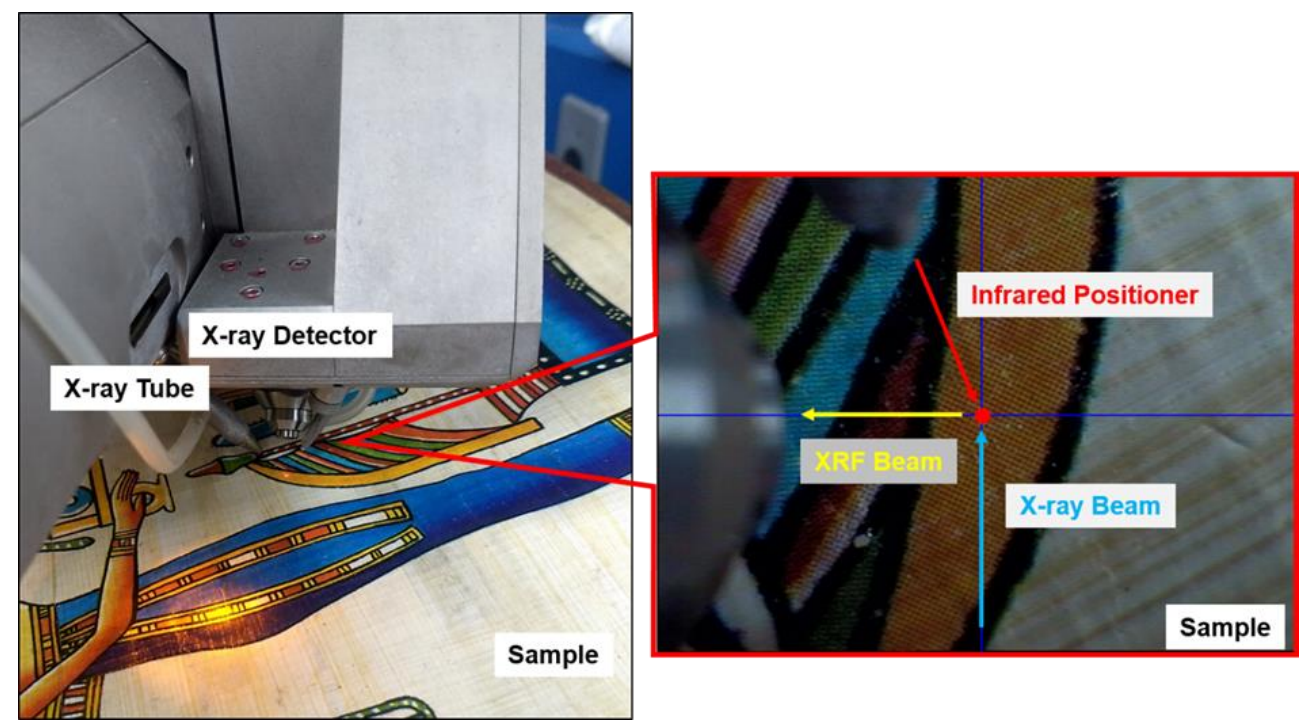

\section{RESULTS AND DISCUSSION}

The characterization of the pigments used in papyrus paintings can be identified by the presence of key elements in the spectra associated with the color of the analyzed region. It should be noted that not all the elements found in the analyzed point are characteristic of the pigment. This is due to the contribution of the XRF lines of the ground layers and also because the colors are often laid one over the other $[5,6]$. The first analyses were on the papyrus sheet, a region without pigment, in 
order to know its elemental composition, our control. Figure 4 shows an XRF spectrum of a region of papyrus without pigments. Both papyri have the same elemental composition.

Figure 4: XRF spectrum of papyrus sheet - region without pigment (control)

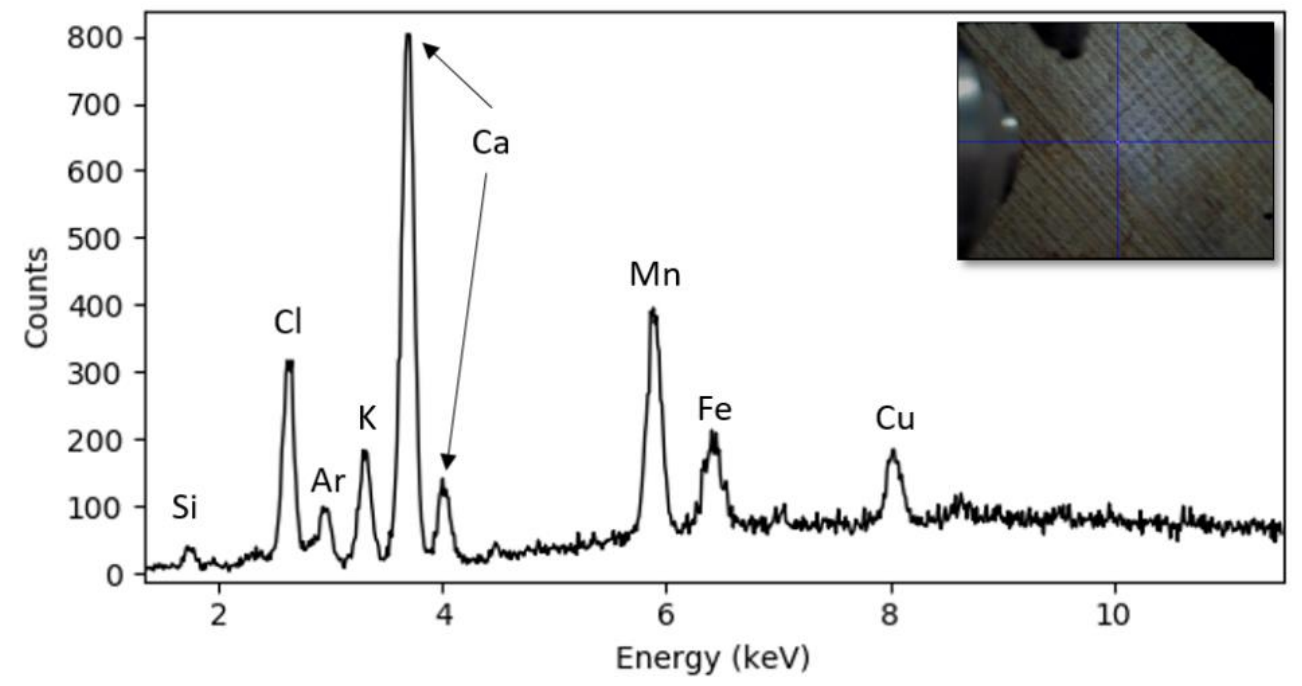

Seven elements were detected in the papyrus sheet: $\mathrm{Si}, \mathrm{Cl}, \mathrm{K}, \mathrm{Ca}, \mathrm{Mn}, \mathrm{Fe}$ and $\mathrm{Cu}$. The XRF analyses were not performed in vacuum and the presence of the Ar in the XRF spectrum is the contribution of the air (dry air contains about $1.0 \%$ of Argon by volume, $1.0 \mathrm{~atm}, 20^{\circ} \mathrm{C}$ ).

\subsection{Papyrus 1 (King Tut and His Wife Scene)}

In the papyrus 1, were analyzed four different colors: Blue, gold, red, and black. The XRF analysis detected seven elements: $\mathrm{S}, \mathrm{Ca}, \mathrm{Mn}, \mathrm{Fe}, \mathrm{Cu}, \mathrm{Zn}$ e Ba. Figure 5 shows the XRF spectra of each pigment analyzed. Based on the elements that exhibited the highest intensities, the possible pigments were established. Table 1 shows the elemental intensities of each color of Papyrus 1.

In the blue pigment, the elements that presented the highest intensities were $\mathrm{Ca}, \mathrm{Cu}, \mathrm{Zn}$ and $\mathrm{Ba}$. The presence of $\mathrm{Ca}$ and $\mathrm{Cu}$ suggest the possibility of Egyptian blue $\left(\mathrm{CaCuSi}_{4} \mathrm{O}_{10}\right)$, the oldest synthetic pigment, produced in Egypt from the 4th Dynasty (2600 BC) [3, 4]. The presence of Zn and $\mathrm{Ba}$ indicate a possible mixture of the Egyptian blue pigment with White Pigment Lithopone $\left(\mathrm{ZnS}+\mathrm{BaSO}_{4}\right)$. White pigments are commonly used as a bleaching agent [8]. However, this white pigment was first synthesized in 1878 [5]. 
Figure 5: XRF spectra of pigments found on the papyrus 1: (a) Blue, (b) Golden, (c) Red and (d) Black.
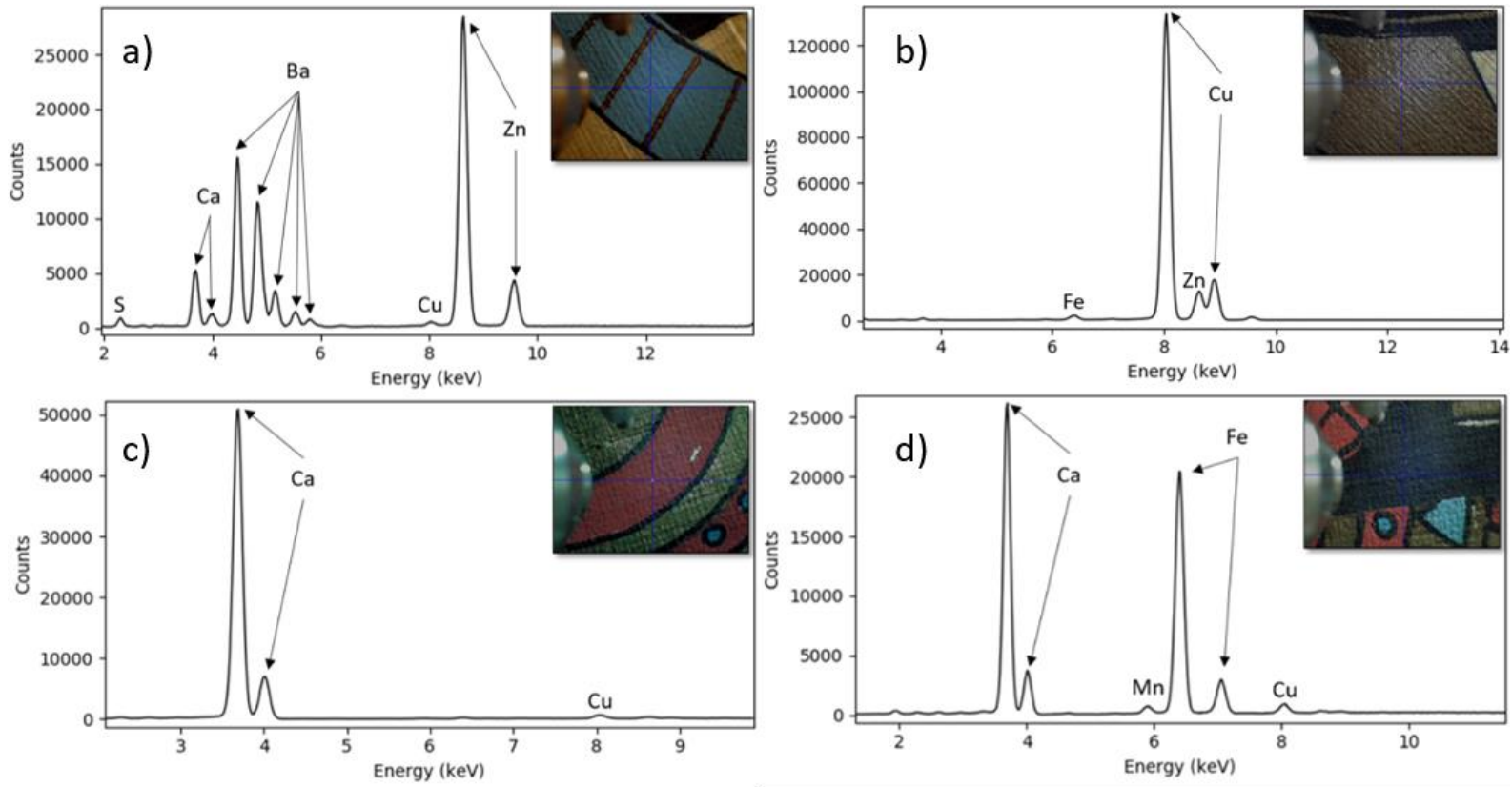

In the gold pigment analysis, $\mathrm{Cu}$ and $\mathrm{Zn}$ presented the highest intensities. The copper-zinc alloy is known as bronze. The gold bronze pigment is obtained by melting respectively copper and zinc raw material. $[6,13]$.

In the red pigment, the highest intensities were exhibited in $\mathrm{Ca}$ and $\mathrm{Cu}$. In this case, probably the contribution of $\mathrm{Cu}$ is due to the nearby golden pigment. At some points on papyrus 1 , the red pigment is above the golden pigment. Besides, according to Calza et al. [5], the minerals hematite (or red ochre) and goethite, used to obtain ochre pigments, can be found associated with cuprite $\left(\mathrm{Cu}_{2} \mathrm{O}\right)$ and other minerals. Thus, only $\mathrm{Ca}$ would be the characteristic element of red. One hypothesis is that perhaps this red pigment is Lithol Bordeaux $2 \mathrm{r}\left(\mathrm{C}_{21} \mathrm{H}_{12} \mathrm{CaN}_{2} \mathrm{O}_{6} \mathrm{~S}\right)$, an organic pigment powder of Chinese origin [14]. The red pigments found in the literature that were used in ancient Egypt are Orpiment $\left(\mathrm{As}_{2} \mathrm{~S}_{3}\right)$; Realgar $\left(\mathrm{As}_{4} \mathrm{~S}_{4}\right)$ and Hematite $\left(\alpha-\mathrm{Fe}_{2} \mathrm{O}_{3}\right)[3,5]$. Anyway, only with $\mathrm{Ca}$ is it not possible to obtain sufficient information about the possible red pigment used in this painting. The XRF technique is able to determine only the elemental composition and not the 
molecular composition of the analyzed samples. However, the presence of calcium in the XRF spectrum obtained in the red pigment may be indicative of an organic pigment.

The organic pigment refers to colored material made of an organic compound with pigment properties. Common types include azo pigments, lake pigments (such as aluminum lakes ( $\mathrm{Al}$ ), calcium lakes $(\mathrm{Ca})$ and Barium $(\mathrm{Ba}))$, phthalocyanine pigments and quinacridone pigments $[15,16]$. Since the organic pigments are derived from minerals, this red pigment found on papyrus 1 may be from mineral source.

In the black pigment, $\mathrm{Ca}$ and $\mathrm{Fe}$ exhibited the highest intensities. There are many possibilities for this pigment. One of them is the magnetite $\left(\mathrm{Fe}_{3} \mathrm{O}_{4}\right)$ and the other possibility is the Asphalt pigment. Asphalt is a complex mixture of organic (bitumen) and inorganic components cannot be characterized by a single chemical formula. The mineral components of Asphalt pigment also vary according to the location where the mineral was found and contain in most cases aluminum silicates and carbonates as well as silicon, aluminum, iron, and calcium oxides [17]. Table 1 shows the elemental intensities of each color of Papyrus 1.

Table 1: The relationship between the detected elements and the pigments present on papyrus 1

$$
(\mathrm{n}=3)
$$

\begin{tabular}{ccccc}
\hline \multirow{2}{*}{ Elements } & \multicolumn{4}{c}{ Color of the analyzed region } \\
\cline { 2 - 5 } & Blue & Golden & Black & Red \\
\hline $\mathbf{S}$ & $7258 \pm 671^{\mathrm{a}}$ & $\mathrm{ND}^{\mathrm{b}}$ & $\mathrm{ND}$ & $\mathrm{ND}$ \\
$\mathbf{C l}$ & $\mathrm{ND}$ & $4951 \pm 1895$ & $1417 \pm 88$ & $1318 \pm 43$ \\
$\mathbf{K}$ & $\mathrm{ND}$ & $\mathrm{ND}$ & $1331 \pm 81$ & $\mathrm{ND}$ \\
$\mathbf{C a}$ & $\mathbf{5 0 3 0 9} \pm \mathbf{7 0 7 9}$ & $6063 \pm 3345$ & $\mathbf{2 6 3 6 6 7} \pm \mathbf{2 8 6 8 8}$ & $\mathbf{5 1 7 3 7 2} \pm \mathbf{6 4 6 5 6}$ \\
$\mathbf{C r}$ & $\mathrm{ND}$ & $615 \pm 152$ & $\mathrm{ND}$ & $\mathrm{ND}$ \\
$\mathbf{M n}$ & $\mathrm{ND}$ & $3031 \pm 696$ & $5547 \pm 1912$ & $\mathrm{ND}$ \\
$\mathbf{F e}$ & $1496 \pm 37$ & $17813 \pm 6773$ & $\mathbf{2 4 0 0 0 6} \pm \mathbf{2 3 4 1 4}$ & $\mathrm{ND}$ \\
$\mathbf{N i}$ & $\mathrm{ND}$ & $\mathrm{ND}$ & $\mathrm{ND}$ & $2678 \pm 229$ \\
$\mathbf{C u}$ & $4439 \pm 629$ & $\mathbf{1 7 8 3 5 7 8} \pm \mathbf{2 1 6 7 2 1}$ & $2352 \pm 781$ & $6754 \pm 1324$ \\
$\mathbf{Z n}$ & $\mathbf{4 0 4 7 6 5} \pm \mathbf{2 7 9}$ & $\mathbf{1 6 4 7 6 8} \pm \mathbf{2 4 4 3 5}$ & $\mathrm{ND}$ & $2748 \pm 431$
\end{tabular}




\begin{tabular}{ccccc} 
Sr & ND & ND & ND & $1151 \pm 127$ \\
Ba & $\mathbf{2 2 1 4 2 5} \pm \mathbf{8 9 3 4}$ & ND & ND & ND \\
\hline
\end{tabular}
a. Mean \pm Standard deviation; b. ND = Element not detected; $c$. Counts in bold = Major elements of each color.

\subsection{Papyrus 2 (The Hunting Scene of the Tomb of Nakht)}

In papyrus 2, five different colors were identified: gold, silver, black, red, and green. The XRF analysis showed the presence of twelve elements: $\mathrm{Si}, \mathrm{Cl}, \mathrm{Ar}, \mathrm{K}, \mathrm{Ca}, \mathrm{Mn}, \mathrm{Fe}, \mathrm{Ni}, \mathrm{Cu}, \mathrm{Zn}$ and $\mathrm{Pb}$. Figure 6 shows the XRF spectra obtained from the pigments. Table 2 shows the elemental intensities of each color of Papyrus 2.

Figure 6: XRF spectra of pigments found on the papyrus 2: (a) Golden, (b) Silver, (c) Black, (d) Red and (e) Green. 

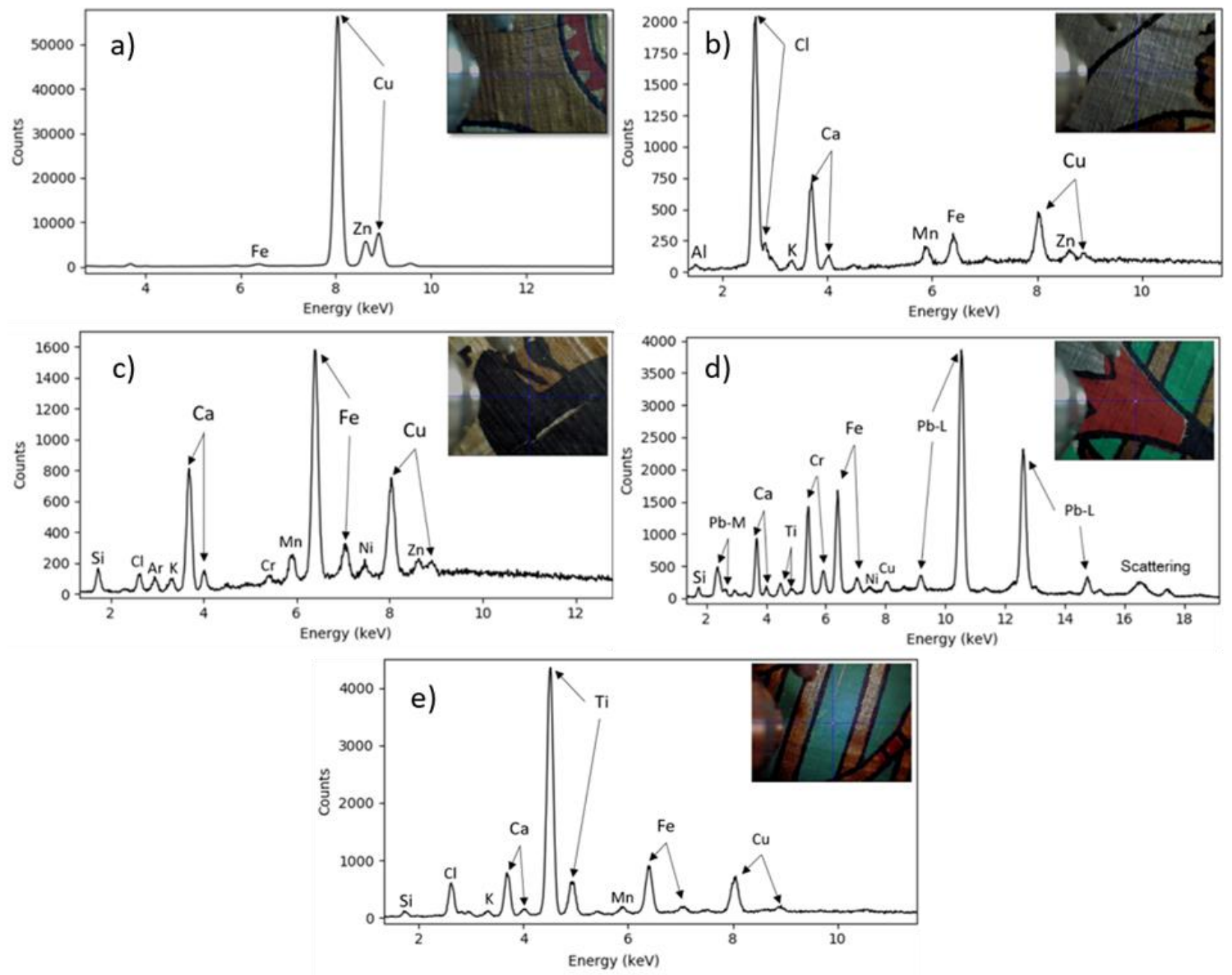

In the gold pigments, the predominant elements detected were: $\mathrm{Cu}$ and $\mathrm{Zn}$ (cf. the situation for papyrus 1). It is probably the same pigment used in papyrus 1 , obtained by melting raw materials of copper and zinc. $[6,13]$.

In the silver pigment, XRF analysis showed the presence of $\mathrm{Al}, \mathrm{Cl}, \mathrm{K}, \mathrm{Ca}, \mathrm{Mn}, \mathrm{Fe}, \mathrm{Cu}$ and $\mathrm{Zn}$. In this pigment, $\mathrm{Cl}$ and $\mathrm{Ca}$ exhibited the highest intensities. Therefore, this may be indicative of the mixing of mineral pigment and a metallic pigment due to the presence of $\mathrm{Fe}, \mathrm{Cu}$ and $\mathrm{Zn}$.

In the black pigment, $\mathrm{Ca}, \mathrm{Fe}$ and $\mathrm{Cu}$ exhibited the highest intensities. The difference between the black pigments in the two papyri is the $\mathrm{Cu}$ intensity. The black color regions analyzed in papyrus 2 are very close to the golden regions; therefore, it should be the contribution of the golden color and not necessarily of the black pigment. As in papyrus 1, for the black pigment, there are 
several possibilities, such as the mixing of different black pigments or the use of the pigment Asphalt [17].

Table 2: Intensities of the major elements on papyrus $2(n=3)$

\begin{tabular}{cccccc}
\hline \multirow{2}{*}{ Elements } & \multicolumn{5}{c}{ Color of the analyzed region } \\
\cline { 2 - 6 } & Golden & Silver & Black & Green & Red \\
\hline $\mathrm{Al}$ & $\mathrm{ND}^{\mathrm{a}}$ & $294 \pm 19^{\mathrm{b}}$ & $\mathrm{ND}$ & $\mathrm{ND}$ & $\mathrm{ND}$ \\
$\mathrm{Si}$ & $\mathrm{ND}$ & $\mathrm{ND}$ & $1484 \pm 230$ & $950 \pm 89$ & $950 \pm 89$ \\
$\mathrm{Cl}$ & $10416 \pm 449$ & $\mathbf{1 9 4 0 9} \pm \mathbf{2 4 6 8}$ & $498 \pm 87$ & $7065 \pm 1075$ & $1275 \pm 213$ \\
$\mathrm{~K}$ & $829 \pm 139$ & $858 \pm 213$ & $745 \pm 111$ & $741 \pm 104$ & $865 \pm 84$ \\
$\mathrm{Ca}$ & $6761 \pm 969$ & $\mathbf{9 7 9 5} \pm \mathbf{2 0 6 6}$ & $\mathbf{7 6 9 9} \pm \mathbf{7 3 5}$ & $7633 \pm 364$ & $245 \pm 135$ \\
$\mathrm{Ti}$ & $\mathrm{ND}$ & $402 \pm 102$ & $\mathrm{ND}$ & $\mathbf{6 6 0 8 1} \pm \mathbf{1 4 7 6 7}$ & $7746 \pm 1719$ \\
$\mathrm{Cr}$ & $\mathrm{ND}$ & $\mathrm{ND}$ & $823 \pm 242$ & $\mathrm{ND}$ & $\mathbf{1 9 4 7} \pm \mathbf{4 5}$ \\
$\mathrm{Mn}$ & $1672 \pm 263$ & $2524 \pm 725$ & $1666 \pm 195$ & $1571 \pm 394$ & $18886 \pm 2571$ \\
$\mathrm{Fe}$ & $7757 \pm 2491$ & $4000 \pm 1938$ & $\mathbf{2 0 5 2 4} \pm \mathbf{2 5 3 0}$ & $\mathbf{1 2 7 0 2} \pm \mathbf{2 3 5 7}$ & $1541 \pm 847$ \\
$\mathrm{Ni}$ & $\mathrm{ND}$ & $\mathrm{ND}$ & $989 \pm 195$ & $520 \pm 149$ & $22154 \pm 2289$ \\
$\mathrm{Cu}$ & $\mathbf{7 0 8 9 0 8} \pm \mathbf{7 2 9 9 0}$ & $\mathrm{ND}$ & $\mathbf{7 8 4 1} \pm \mathbf{1 6 0 7}$ & $10612 \pm 2333$ & $1052 \pm 181$ \\
$\mathrm{Zn}$ & $\mathbf{7 2 3 8 2} \pm \mathbf{7 4 9 2}$ & $4083 \pm 827$ & $437 \pm 81$ & $575 \pm 231$ & $2637 \pm 1494$ \\
$\mathrm{~Pb}$ & $\mathrm{ND}$ & $\mathrm{ND}$ & $\mathrm{ND}$ & $1078 \pm 393$ & $\mathbf{9 7 9 0 6} \pm \mathbf{1 5 5 6 8}$ \\
\hline
\end{tabular}

a. $\quad$ Mean \pm Standard deviation; b. ND = Element not detected; c. Counts in bold $=$ Major elements of each color.

In the red pigment, the elements that presented the highest intensities were $\mathrm{Pb}, \mathrm{Fe}$ and $\mathrm{Cr}$. The presence of $\mathrm{Pb}$ and $\mathrm{Cr}$ suggests the possibility of Chrome $\mathrm{Red}\left(\mathrm{PbCrO}_{4} \cdot \mathrm{Pb}(\mathrm{OH})_{2}\right)$, a modern pigment, first synthesized in the early nineteenth century $[5,8]$.

In the green pigment, the elements with the highest intensities were $\mathrm{Ti}, \mathrm{Ca}, \mathrm{Fe}$ and $\mathrm{Cu}$. $\mathrm{The}$ presence of $\mathrm{Fe}$ and $\mathrm{K}$ suggests the possibilities of Terra Verde ( $\mathrm{K}$ [( $\left.\left.\mathrm{Al}^{\mathrm{III}}, \mathrm{Fe}^{\mathrm{III}}\right)\left(\mathrm{Fe}^{\mathrm{II}}, \mathrm{Mg}^{\mathrm{II}}\right)\right]$, $\left.\left(\mathrm{AlSi}_{3}, \mathrm{Si} 4\right) \mathrm{O}_{10}(\mathrm{OH})_{2}\right)$, a pigment of mineral origin used since ancient times [3, 4]. Besides, the presence of $\mathrm{Cu}$ may also indicate Verdigris $\left(\mathrm{Cu}\left(\mathrm{C}_{2} \mathrm{H}_{3} \mathrm{O}_{2}\right)_{2} 2 \mathrm{Cu}(\mathrm{OH})_{2}\right)$, mineral and synthetic pigment (BC), or Malachite $\left(\mathrm{CuCO}_{3} \mathrm{Cu}(\mathrm{OH})_{2}\right)$, mineral pigment [5]. The presence of Ti in pigment is usually associated with modern pigments. However, the presence of Ti could indicate the use of 
the white pigment, Anatase $\left(\mathrm{TiO}_{2}\right)$, first synthesized in 1923 or Rutile $\left(\mathrm{TiO}_{2}\right)$ started in 1947 [8]. For the green pigment present in papyrus 2, as well as for the black pigment present in the two papyrus, there are several possibilities, because the XRF technique is able to determine only the elemental composition and not the chemical forms of the samples analyzed.

A summary of the major elements identified on each papyrus is given in Table 3.

Table 3. Major elements detected on the two papyrus

\begin{tabular}{|c|c|c|c|}
\hline & Color & Major elements & Possible pigment \\
\hline Papyrus leaf & No color & $\mathrm{Si}, \mathrm{S}, \mathbf{C l}^{\mathrm{a}}, \mathrm{K}, \mathbf{C a}, \mathbf{M n}, \mathrm{Fe}, \mathrm{Cu}$ & $\mathrm{NI}^{\mathrm{b}}$ \\
\hline \multirow{4}{*}{ Papyrus 1} & Blue & $\mathrm{S}, \mathrm{K}, \mathrm{Ca}, \mathrm{Fe}, \mathrm{Cu}, \mathbf{Z n}, \mathbf{B a}$ & $\begin{array}{l}\text { Egyptian Blue } \\
\text { + Lithopone }\end{array}$ \\
\hline & Golden & $\mathrm{Cl}, \mathrm{Ca}, \mathrm{Mn}, \mathrm{Fe}, \mathrm{Cu}, \mathbf{Z n}$ & Copper-zinc \\
\hline & Black & $\mathrm{S}, \mathrm{Cl}, \mathbf{C a}, \mathrm{Mn}, \mathbf{F e}, \mathrm{Cu}, \mathrm{Zn}$ & NI \\
\hline & Red & $\mathrm{S}, \mathrm{Cl}, \mathrm{K}, \mathbf{C a}, \mathrm{Ti}, \mathrm{Mn}, \mathrm{Fe}, \mathbf{C u}, \mathrm{Zn}$ & Mineral \\
\hline \multirow{5}{*}{ Papyrus 2} & Golden & $\mathrm{Cl}, \mathrm{K}, \mathrm{Ca}, \mathrm{Mn}, \mathrm{Fe}, \mathbf{C u}, \mathbf{Z n}$ & Copper-zinc \\
\hline & Silver & $\mathrm{Al}, \mathbf{C l}, \mathrm{K}, \mathbf{C a}, \mathrm{Ti}, \mathrm{Mn}, \mathrm{Fe}, \mathbf{C u}, \mathrm{Zn}$ & NI \\
\hline & Black & $\mathrm{Si}, \mathrm{Cl}, \mathrm{K}, \mathrm{Ca}, \mathrm{Cr}, \mathrm{Mn}, \mathbf{F e}, \mathrm{Ni}, \mathbf{C u}, \mathrm{Zn}$ & NI \\
\hline & Green & $\mathrm{Si}, \mathrm{Cl}, \mathrm{K}, \mathrm{Ca}, \mathrm{Ti}, \mathrm{Mn}, \mathrm{Fe}, \mathrm{Ni}, \mathrm{Cu}, \mathrm{Zn}, \mathrm{Pb}$ & NI \\
\hline & Red & $\mathrm{Si}, \mathrm{K}, \mathrm{Ca}, \mathrm{Ti}, \mathbf{C r}, \mathrm{Mn}, \mathbf{F e}, \mathrm{Ni}, \mathrm{Cu}, \mathrm{Zn}, \mathbf{P b}$ & Chrome red \\
\hline
\end{tabular}

a) The elements in bold correspond to the major elements;

b) $\mathrm{NI}=$ the detected elements have not provided enough information to link them to any possible pigment

\section{CONCLUSION}

The present work characterized the elemental composition of the pigments used in two modern papyrus paintings belonging to a private collection using XRF. Four pigments were analyzed in papyrus 1 (blue, golden, red, and black) and five pigments in papyrus 2 (golden, silver, black, red, and green). The analysis of the papyrus sheet showed the same elemental composition in both papyri. 
Golden, red, and black colors are common in both papyri. The XRF spectra of the golden pigments suggest the possibility that both are the same pigment, formed by the copper-zinc alloy. The XRF spectra of the black and red pigments were discrepant from each other. Despite having the same color, possibly the pigments were synthesized with different raw materials.

The possible blue pigment found in the Papyrus 1 (Egyptian blue) is in accordance with the used by Egyptian craftsmen from $2600 \mathrm{BC}$, however, the XRF spectrum also showed the presence of the $\mathrm{Ba}$ and $\mathrm{Zn}$, elements associated a modern white pigment, Lithopone. This may be indicative of possible mixing with Egyptian blue and Lithopone. Thus, the possible pigments found in the samples do not follow those used in ancient Egypt. Through the XRF technique, it was possible to verify that the pigments used in both papyri were recognized as modern and are not part of the pigments used in ancient Egypt. 


\section{ACKNOWLEDGMENT}

This study was financed in part by the Conselho Nacional de Desenvolvimento Científico e Tecnológico (CNPq), the Fundação Carlos Chagas Filho de Amparo à Pesquisa do Estado do Rio de Janeiro (FAPERJ) and Coordenação de Aperfeiçoamento de Pessoal de Nível Superior - Brazil (CAPES) - finance code 001 and Financiadora de Estudos e Projetos (FINEP - CT-INFRA 01.13.0444.02).

\section{REFERENCES}

[1] ESPINEL A. D., Papyrus, The Encyclopedia of Ancient History, v. 1, p. 5055-5057, 2013.

[2] PAPYRUS MAKING 101: An Introduction to Papyrus - Ancient and Modern. University Library system at the University of Michigan. 2004. Available at: <https://www.lib.umich.edu/papyrus_making/pm_intro.html>. Last accessed:14 Nov. 2018

[3] DI STEFANO L. M., FUCHS R., Characterisation of the pigments in a Ptolemaic Egyptian Book of the Dead papyrus, Archaeol Anthropol Sci, v. 3, p. 229-244, 2011.

[4] GOLER, S., YARDLEY, J. T., CACCIOLA, A., HAGADORN, A., RATZAN, D., BAGNALL, R., Characterizing the age of ancient Egyptian manuscripts through micro-Raman spectroscopy, Journal Raman Spectroscopy, v. 47, p. 1185-1193, 2016.

[5] CALZA, C., ANJOS, M. J., DE SOUZA, S. M. F. M., BRANCAGLION JR., A., LOPES, R. T., $\mathrm{X}$-ray microfluorescence with synchrotron radiation applied in the analysis of pigments from ancient Egypt, Appl. Phys.A, v. 90, p. 75-79, 2008.

[6] BURGIO, L., CLARK, R. J. H., Comparative pigment analysis of six modern Egyptian papyri and an authentic one of the 13th century BC by Raman microscopy and other techniques, $\mathbf{J}$. Raman Spectrosc., v. 31, p. 395-401, 2000.

[7] RIEDERER, J., Recently Identified Egyptian Pigments, Archaeometry, v. 16, p. 102-109, 1974. 
[8] .KAJIYAA, E. A. M., CAMPOSA, P. H. O.V., RIZZUTTO, M.A, et al., Evaluation of the veracity of one work by the artist Di Cavalcanti through non-destructive techniques: XRF, imaging and brush stroke analysis, Radiation Physics and Chemistry, v. 95, p. 373-377, 2014.

[9] ROSIA, F., BURNSTOCK, A., , VAN DEN BERG, K. J., et al., A non-invasive XRF study supported by multivariate statistical analysis and reflectance FTIR to assess the composition of modern painting materials, Spectrochimica Acta Part A: Molecular and Biomolecular Spectroscopy, v. 71, p. 1655-1662, 2009.

[10] ABDRABOU, A., EL HADIDI, N. M. N., HAMED, S., ABDALlAH, M., Multidisciplinary approach for the investigation and analysis of a gilded wooden bed of King Tutankhamun, Journal of Archaeological Science: Reports, v. 21, p. 553-564, 2018.

[11] BENDERITTER, T. Osirisnet - Tomb of Ancient Egypt: Nakht TT52. . Available at: <https://www.osirisnet.net/tombes/nobles/nakht52/e_nakht_01.htm>. Last accessed: 8 Sept. 2018.

[12] SOlÉ, V.A., PAPILlON, E., COTTE, M., WALTER, P., SUSINI, J., A multiplatform code for the analysis of energy-dispersive X-ray fluorescence spectra, Spectrochimica Acta Part B: Atomic Spectroscopy, v. 62, p. 63-68, 2007.

[13] AVL METAL POWDERS. Aluminium pigments. Available at: <https://www.avlmetalpowders.com/en/sector-products/plastic-materials/pigment-range> Last accessed: 6 Apr. 2019

[14] CHEMICAL BOOK. Pigment Red 63:1 Basic information. Available at: <https://www.chemicalbook.com/ProductChemicalPropertiesCB0854904_EN.htm>. Last accessed: 20 June 2019

[15] KOEL COLOURS PRIVATE LIMITED. Difference between Organic Pigments and Inorganic Pigments. Available at: <https://www.koelcolours.com/blog/pigments/differenceorganic-pigments-inorganic-pigments/ Last accessed: 15 May. 2018

[16] CHEMICAL BOOK. Organic pigments. Available at: <https://www.chemicalbook.com/ProductCatalog_EN/161211.htm>. Last accessed: 20 June 2019

[17] COLOURLEX. Composition and Properties of Asphalt. Available at: <https://colourlex.com/project/asphalt/>. Last accessed: 14 July 2019. 
